\title{
Pengaruh Pelayanan dan Kualitas Produk Terhadap Loyalitas Pelanggan
}

\author{
Jan Horas Veryady Purba \\ Program Studi Manajemen, Sekolah Tinggi Ilmu Ekonomi Kesatuan \\ Bogor, Indonesia \\ Sulistiono \\ Program Studi Manajemen, Sekolah Tinggi Ilmu Ekonomi Kesatuan \\ Bogor, Indonesia \\ E-Mail: anggaslt@gmail.com
}

Submitted:

FEBRUARI 2013

Accepted:

MARET 2013

\begin{abstract}
Service and product quality is an important factor in order that an enterprise keeps running competition. The enterprise has to cultivate good relationship with the customers and keeps striving to increase service and product quality so that the consuners keep having loyalty to the enterprise. To get competitive excellence, every enterprise must be able to satisfy the consummers. Therefore, the strategy based on the management's commitment to increase service and product quality to satisfy the consumers should be done continually, thereby the consumers' satisfaction will be created.

This research was conducted to find out the effect of service and pruduct quality on the consumers' loyalty to the enterprise, that is McDonald's. The method used is interviewing, library study, and field research by questionnaire. The research was carried out at McDonald's Indonesia located in Jalan Pajajaran Bogor. McDonald's Indonesia is an enterprise producing food and beverage. The evaluation result on this research shows that the steps done by McDonald's in maintaining The consumers' loyalty are providing service and product quality and providing better and more comfortable oulet for the consumers. It should be taken note of as well, that is providing more and more satisfied service and product quality and creating more variation of its products, so that the consumers will be attracted to by them. Thereby, the enterprise has to maintain the consumers to be more loyal to McDonald's.
\end{abstract}

Keywords:service; product quality; consumers' loyalty

\section{PENDAHULUAN}

Dalam ilmu ekonomi, prinsip loyalitas berawal dari adanya kepuasan pelanggan, yang muncul dengan adanya kualitas (baik produk, pelayanan, maupun hubungan). Oleh karena itu, dibutuhkan pengetahuan dan pemahaman yang lebih konkrit mengenai faktor-faktor penentu respon pelanggan terhadap kepuasan pelanggan, ada pilihanpilihan yang dapat dikembangkan lebih lanjut: apakah pemasar berfokus kepada pemasaran individual, atau lebih memilih untuk menambah unsur kualitas dengan mengembangkan aspek pilihan. Misalnya hal itu dilakukan dengan membuat deferensiasi produk untuk menjamin pelanggan agar mendapatkan penawaran khas sesuai kebutuhan mereka.

Berbagai temuan mengenai tantangan tersebut telah dicapai oleh para peneliti terdahulu seperti yang terdapat pada buku-buku pemasaran (Kotler, 2008) serta para dosen menekankan pentingnya pemasaran individual, alat-alat dan pendekatan manajemen yang baru telah diperkenalkan untuk memungkinkan para pemasar melayani keinginan para pelanggan individual secara lebih baik.

Pendekatan semacam itu telah dibahas (Peppers dan Rogers 1999). Meskipun tiap pendekatan manajemen itu mempunyai berbagai aspek unik, tetapi persamaan asumsi

\section{JIMKES}

Jurnal Ilmiah Manajemen Kesatuan Vol. 1 No. 1,2013 pp. $85-92$ ISSN $2337-7860$ 
Service, Quality \& Loyalty

86 dasarnya ialah para pelanggan punya pilihan tersembunyi dan terselubung yang dapat diungkap oleh para pemasar dengan cara membangun hubungan pembelajaran. Tentu saja sesudah pemasar mengetahui pilihan pelanggan, penawaran mengenai apa yang mereka inginkan dapat dilakukan oleh pemasar. Jika sukses, para pemasar akan dihargai atas nilai keunggulan (advantage value) yang diberikan dengan loyalitas pelanggan yang lebih tinggi, yang akan menciptakan "halangan yang tak dapat diatasi untuk persaingan, bagi satu pelanggan individual pada waktu tertentu" (Peppers dan Rogers, 1999).

Mempelajari pilihan pelanggan individual dan menyesuaikan penawaran untuk pilihan-pilihan tersebut bukanlah konsep baru dan telah menjadi praktik baku di berbagai bidang jasa, bisnis-untuk-bisnis, dan pasar lainnya. Namun, teknologi baru kini memungkinkan para pemasar menerapkan Individual Marketing dengan menggunakan tawaran khusus secara massal diberbagai jenis pasar yang lebih luas (Simonson, 2005:25).Dengan berpegang pada orientasi pelanggan, tujuan yang ingin dicapai perusahaan ialah memberikan kepuasan pelanggan (customer satisfaction) karena sebenarnya kepuasan merupakan kunci untuk mempertahankan pelanggan. Bila pelanggan merasa puas, selain mereka setia pada produk yang memuaskan mereka, kesetiaan mereka lebih lama, sehingga kemungkinkan pelanggan beralih mendadak ke produk lain sangat lecil, meskipun harga produk lain lebih murah. Kepuasan pelanggan di butuhkan untuk ekspansi bisnis, untuk memperoleh market share yang lebih tinggi dan pengulangan pembelian secara keseluruhan akan membawa pada pelanggan profitabilitas (Belk, 1986). Kepuasan pelanggan bisa dievaluasi berdasarkan beberapa aspek: Diskonfirmasi, harapan pelangan, kewajaran harga (Kotler, et al2004:67), persepsi kualitas (Parasuraman et al., 2006:37). Disamping dipengaruhi oleh variabel di atas, kepuasan juga dipengaruhi oleh repurchases dan intensitas complain.

Penelitian lain menemukan bahwa kepuasan pelanggan juga dipengaruhi oleh kualitas layanan (service quality), problem eksperience (Parasuraman et al., 2006:48). Dilain pihak ditemukan bahwa kepuasan pelanggan dipengaruhi oleh image dan loyalitas pelanggan (Bowen et al., 2001:112). Dalam sektor jasa seperti fast food, dry cleaning, menemukan kepuasan pelanggan berpengaruh secara signifikan pada intensitas pembelian ulang dalam semua sektor.Gilbert (2003:78) dalam penelitiannya mengenai konseptualisasi dan pengukuran kualitas jasa dan hubungan antar kualitas jasa, kepuasan pelanggan serta niat membeli, menjelaskan bahwa operasionalisasi kualitas jasa kini membaur dengan kepuasan serta sikap. Oleh karena itu, para peneliti menguji (1) metode alternatif untuk mengoperasionalkan kualitas jasa yang dirasakan, dan (2) menyoroti pentingnya hubungan antara kualitas jasa, kepuasan pelanggan, dan niat membeli.

Hasilnya menunjukkan hal-hal berikut : Pertama, ukuran kualitas jasa yang didasarkan pada kinerja bisa menjadi sarana pengukuran konsepsi kualitas jasa yang lebih baik. Kedua, kualitas jasa merupakan pendahulu dari kepuasan pelanggan. Ketiga, kepuasan pelanggan memiliki efek yang signifikan terhadap niat membeli, dan Keempat, kualitas jasa memiliki efek terhadap niat membeli dari pada kepuasan pelanggan.

\section{METODE PENELITIAN}

Metode yang digunakan dalam penelitian ini adalah dengan menggunakan Metode Deskriptif, yaitu dengan menggambarkan atau melukiskan keadaan subjek/objek penelitian pada saat sekarang berdasarkan fakta-fakta yang tampak atau sebagaimana adanya untuk mendapatkan kesimpulan dari masalah yang ada dan dicarikan pemecahannya.

Adapun dalam penelitian deskriptif ini dilakukan untuk memperoleh gambaran jelas antara pengaruh layanan tehadap loyalitas pelanggan, pengaruh kualitas produk terhadap loyalitas pelanggan, dan pengaruh layanan dan kualitas produk terhadap loyalitas pelanggan pada perusahaan yang bersangkutan. 
Dalam pengolahan dan analisis data, penulis menggunakan analisis regresi ganda yang merupakan pengembangan dari analisis regresi sederhana. Kegunaannya adalah untuk meramalkan nilai variabel terikat $(\mathrm{Y})$ apabila variabel bebasnya $(\mathrm{X})$ dua atau lebih. Pengambilan sampel dilakukan dengan menggunakan jumlah pelanggan yang ada pada pertengahan tahun 2010 sebagai jumlah populasi yang kemudian akan penulis masukan kedalam rumus pengambilan sampel dari Slovin dengan persentase kelonggaran karena kesalahan yang masih dapat ditolelir sebesar 10 $\%$.Untukmempermudah penyimpulan, penulis menggunakan rumus korelasi produk moment dimana variabel yang digunakan adalah variabel layanan, variabel kualitas produk dan variabel loyalitas pelanggan

\section{HASIL DAN PEMBAHASAN}

Pengaruh Pelayanan dan Kualitas Produk Terhadap Loyalitas Pelanggan pada McDonald's Hero Pajajaran Bogor

Untuk menjawab apakah ada pengaruh antara pelayanan dan kualitas produk terhadap loyalitas pelanggan maka penulis menggunakan analisis regresi linier berganda, dimana hasil pengolahan data, sebagai berikut :

Tabel 1Variabel $\mathrm{X}_{1}, \mathrm{X}_{2}$ dan $\mathrm{Y}$

\begin{tabular}{|c|c|c|c|c|c|c|c|c|c|}
\hline & $\mathbf{X}_{1}$ & $\mathbf{X}_{2}$ & $\mathrm{Y}$ & $\mathrm{X}_{1}{ }^{2}$ & $\mathrm{X}_{2}{ }^{2}$ & $\mathrm{Y}^{2}$ & $\mathrm{X}_{1} \cdot \mathrm{X}_{2}$ & $\mathrm{X}_{1} \cdot \mathrm{Y}$ & $\mathrm{X}_{2} \cdot \mathrm{Y}$ \\
\hline$\sum$ & 2618 & 2765 & 2944 & $\mathbf{6 9 7 0 6}$ & $\mathbf{7 7 9 5 9}$ & $\mathbf{8 7 4 3 2}$ & $\mathbf{7 3 1 7 0}$ & $\mathbf{7 7 5 1 2}$ & $\mathbf{8 2 0 4 2}$ \\
\hline
\end{tabular}

\section{Regresi X1 dan X2 terhadap Y}

Pengaruh Pelayanan dan Kualitas Produk terhadap Loyalitas Pelanggan.

Tabel 2 Model Summary

\begin{tabular}{|c|c|r|r|r|}
\hline Model & R & \multicolumn{1}{|c|}{ R Square } & Adjusted R Square & Std. Error of the Estimate \\
\hline 1 & $.601^{\mathrm{a}}$ & .361 & .354 & 2.22737 \\
\hline
\end{tabular}

a. Predictors: (Constant), Pelayanan dan Kualitas Produk

Tabel 3 ANOVA ${ }^{b}$

\begin{tabular}{|ll|r|r|r|c|c|}
\hline \multicolumn{1}{|l|}{ Model } & Sum of Squares & Df & Mean Square & F & Sig. \\
\hline 1 & Regression & 274.443 & 1 & 274.443 & 55.318 & $.000^{\mathrm{a}}$ \\
& Residual & 486.197 & 98 & 4.961 & & \\
Total & 760.640 & 99 & & & \\
\hline
\end{tabular}

a. Predictors: (Constant), Pelayanan dan Kualitas Produk

b. Dependent Variable: Loyalitas pelanggan

Rumusan Hipotesis Statistik $\mathbf{H}_{0}$ dan $\mathbf{H}_{1}$.

$\mathrm{H}_{0}: \mathrm{R}=0$ : Tidak terdapat pengaruh layanan dan kualitas produk secara bersama-sama terhadap loyalitas pelanggan.

$\mathrm{H}_{1}: \mathrm{R} \neq 0$ : Terdapat pengaruh layanan dan kualitas produk secara bersamasama terhadap loyalitas pelanggan.

\section{Menentukan uji statistik}

$$
F=\frac{S_{1}{ }^{2}}{S_{2}{ }^{2}}
$$

\section{Menentukan Jumlah Kuadrat Regresi a}

$$
J K_{(\mathrm{REG})}=\sum Y^{2}=87432 .
$$

Menentukan jumlah Kuadrat Regresi a $\mid \mathbf{b}$

$$
J K_{(R E G \quad a b)}=\mathrm{b}_{1} \sum \mathrm{x}_{1} \mathrm{y}+\mathrm{b}_{2} \sum \mathrm{x}_{2} \mathrm{y}
$$




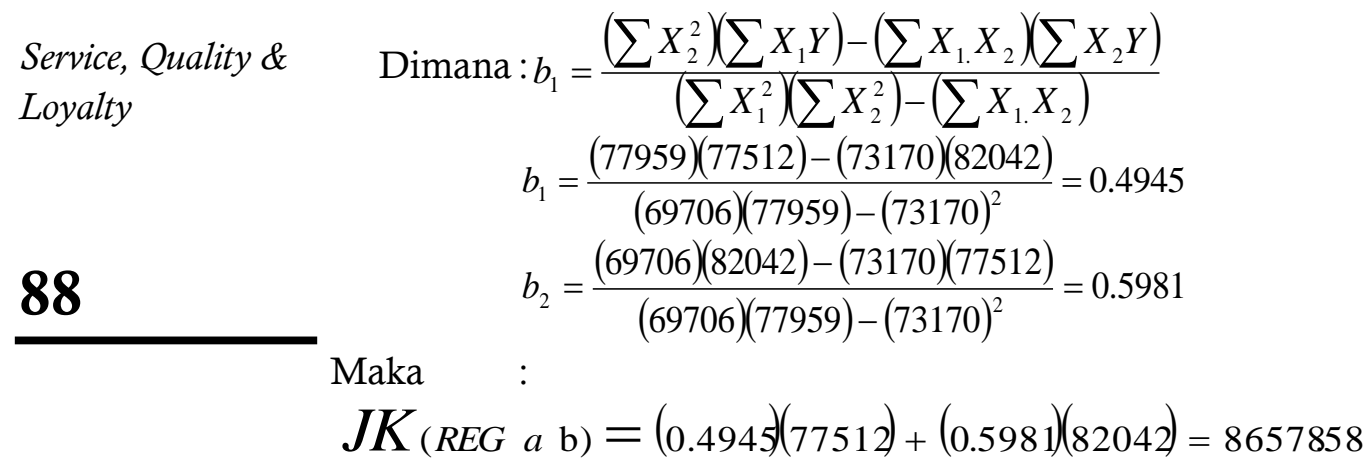

Menentukan Jumlah Kuadrat Residu Jk (S)

$J K(\mathrm{~s})=\mathrm{JK}_{(R E G a)}-\mathrm{JK}_{(\mathrm{REG} \mathrm{b})}$

$J K(\mathrm{~s})=87432-86578.58=853.4158$

Menghitung Nilai F

$$
F_{\text {hitung }}=\frac{\frac{J K(\mathrm{REG})}{2}}{\frac{J \mathrm{~K}(\mathrm{~S})}{\mathrm{n}-3}} F_{\text {hitung }}=\frac{426.7079}{8.7981}=48.500
$$

Menentukan Nilai Kritis (a) dengan derajat kebebasan (df) untuk:

$\mathrm{Db}_{\text {reg }}=1$ dan $\mathrm{db}_{\text {res }}=100-3=97$

pada $\mathrm{a}=10 \%$ dimana

$\mathrm{db}$ reg $=2$ adalah 2.7579

Membandingkan nilai uji $F$ terhadap nilai tabel $F$

Dengan demikian nilai uji $\mathrm{F} 48,500 \geq$ nilai tabel $\mathrm{F} 2.7579$, maka tolak $\mathrm{H}_{0}$, yang artinya koefisien regresi di atas signifikan (berarti).

\section{Membuat kesimpulan}

Membuat kesimpulan yang kemudian diberi ringkasan, yaitu ringkasan variabel loyalitas pelanggan $(\mathrm{Y})$ atas variabel layanan $\left(\mathrm{X}_{1}\right)$ dan variabel kualitas produk $\left(\mathrm{X}_{2}\right)$ dalam tabel ANOVA dibawah ini :

Tabel 4 Perbandingan Nilai $F$

\begin{tabular}{|l|c|c|r|r|c|}
\hline \multicolumn{1}{|c|}{ Sumber Variasi } & Dk & JK & KT & F HITUNG & F TABEL \\
\hline Total & N & 87432 & - & & \multirow{2}{*}{2.7579} \\
\cline { 1 - 4 } Regresi (b & 2 & 86578,58 & 426,7079 & 48,500 & \\
\hline Sisa & n-3 & 853,4158 & 8,7981 & & \\
\hline
\end{tabular}

$a=\bar{y}-b_{1} \bar{x}_{1}-b_{2} \bar{x}_{2}=29.44-0.4945(26.18)-0.5881(27.65)=0.23309$

$Y=a+b_{1} x_{1}+b_{2} x_{2}=0.23309+0.4945(1)+0.5881(1)=1.31569$

Dari hasil analisis regresi linier diatas, diketahui bahwa fungsi $y=0.23309+0.4945(x)+0.5881(x)$. Hasil ini mengandung arti bahwa jika Layanan dan Kualitas Produk dinaikan sebesar 1, maka persamaan akan berubah menjadi $\mathrm{y}=0.23309+0,4945(1)+0.5881$ (1) yang berarti bahwa atau loyalitas pelanggan pada saat ini adalah sebesar 1.31569. Persamaan regresi ini-pun berfungsi untuk meramalkan loyalitas pelanggan dimasa yang akan datang. Dengan demikian, jika variabel $\left(\mathrm{x}_{1}\right)$ Layanan dan $\left(\mathrm{x}_{2}\right)$ Kualitas Produk berubah maka variabel (y) Loyalitas Pelanggan-pun akan berubah.

\section{Koefisien Korelasi}

Untuk mengetahui seberapa besar keeratan antara Layanan dan Kualitas Produkdengan Loyalitas Pelanggan, maka sebelumnya dihitung terlebih dahulu untuk koefisien korelasi antara Layanan dengan Kualitas Produk dapat diketahui dengan menggunakan rumus koefesien korelasi, seperti perhitungan di bawah ini : 


$$
r=\frac{n\left(\sum x_{1} x_{2}\right)-\left(\sum x_{1}\right)\left(\sum x_{2}\right)}{\sqrt{\left\{n\left(\sum x_{1}^{2}\right)-\left(\sum x_{1}\right)^{2}\right\}\left\{n\left(\sum x_{2}^{2}\right)-\left(\sum x_{2}\right)^{2}\right\}}}
$$

Dimana:

$r \quad=$ Koefisien korelasi

$\mathrm{x}_{1}$ = Layanan

$\mathrm{x}_{2}=$ Kualitas Produk

$\mathrm{n} \quad=$ Jumlah sampel

$$
r_{x y}=\frac{100.73170-(2618) \cdot(2765)}{\sqrt{100.69706-(2618)^{2} \mid 100.77959-(2765)^{2}}} r_{x y}=0,590
$$

Untuk mengetahui kuat tidaknya hubungan antara variabel layanan $\left(\mathrm{X}_{1}\right)$ dan variabel $\left(\mathrm{X}_{2}\right)$ secara bersama - sama dengan variabel loyalitas pelanggan $(\mathrm{Y})$. Dengan rumus :

$$
\begin{aligned}
& R_{x 1 x 2 y}=\sqrt{\frac{r_{x 1 y}^{2}+r_{x 2 y}^{2}-2 \cdot r_{x 1 y} \cdot r_{x 2 y} \cdot r_{x 1 x 2}}{1-r_{x 1 x 2}^{2}}} \\
& R_{x 1 x 2 y}=\sqrt{\frac{0,465^{2}+0,598^{2}-2 \cdot(0,465) \cdot(0,598) \cdot(0,590)}{1-0,590^{2}}} R_{x 1 x 2 y}=0,614
\end{aligned}
$$

Dari hasil perhitungan diatas didapatkan angka korelasi antara Layanan dan Kualitas Produk dengan loyalitas pelanggan sebesar 0,614. Artinya, hubungan kedua variabel tersebut Kuat. Korelasi positif menunjukkan bahwa hubungan antara Layanan dan Kualitas Produk dengan loyalitas pelanggan searah. Artinya jika Layanan dan Kualitas Produk ditingkatkan maka loyalitas pelanggan akan meningkat.

Untuk melihat hubungan antara variabel Layanan dan Kualitas Produk dengan loyalitas pelanggan signifikan atau tidak dapat dilakukan uji statistik. Dengan menentukan rumusan hipotesis statistik

$\mathrm{H}_{0}: \rho_{\mathrm{y}(\mathrm{x} 1 \times 2)}=0=$ Tidak ada hubungan antara variabel $\mathrm{X}_{1}$ dan $\mathrm{X}_{2}$ dengan variabel $\mathrm{Y}$.

$\mathrm{H}_{1}: \rho_{\mathrm{y}(\mathrm{x} 1 \times 2} \neq 0=$ Ada hubungan antara variabel $\mathrm{X}_{1}$ dan $\mathrm{X}_{2}$ dengan variabel $\mathrm{Y}$

Untuk mengetahui apakah hubungan antar variabel diatas berarti atau tidak, maka dilakukan pengujian keberartian koefisien korelasi parsial dengan menggunakan rumus :

$$
F=\frac{\frac{R_{x 1 \times 2 y}}{k}}{\frac{1-R^{2} x_{x 2 y}}{n-k-1}} F=\frac{\frac{0,6138}{3}}{\frac{1-0,6138^{2}}{100-3-1}}=31,5123
$$

Harga $\mathrm{f}$ hitung tersebut kemudian dibandingkan dengan harga $\mathrm{f}$ tabel untuk kesalahan $10 \%$ Nilai dan titik kritis pada $d b 1=3$ dan $d b 2=96$ adalah 2.141. Hal ini dapat digambarkan seperti pada gambar dibawah ini :

$$
31,5123
$$

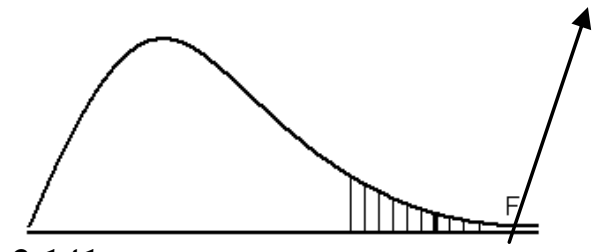

2,141

Gambar 1HubunganPelayanan dan Kualitas Produk dengan Loyalitas Pelanggan

Berdasarkan perhitungan yang ditunjukan pada gambar diatas, maka dinyatakan bahwa t hitung jatuh pada daerah penolakan $\mathrm{H}_{0}$, maka dapat dinyatakan hipotesis nol yang menyatakan tidak ada hubungan antara Layanan dan Kualitas Produk dengan 
Service, Quality \& Loyalty loyalitas Pelanggan ditolak. Yang berarti hipotesis alternatif yang menyatakan ada hubungan antara Layanan dan Kualitas Produk dengan Loyalitas Pelanggan diterima. Jadi kesimpulan-nya koefisien korelasi antara Layanan dan Kualitas Produk dengan Loyalitas Pelanggan sebesar $r=0.614$ adalah signifikan, artinya koefisien tersebut dapat digeneralisasikan atau berlaku pada seluruh populasi dimana sampel yang 100 diambil. Setelah diketahui koefisien korelasinya, maka selanjutnya untuk mengetahui kontribusi Layanan dan Kualitas Produk dalam menciptakan Loyalitas Pelanggan, digunakanlah perhitungan seperti dibawah ini.

\section{Koefisien Determinasi}

$$
\begin{aligned}
K D & =r^{2} x 100 \% \\
K D & =0.614^{2} x 100 \% \\
K D & =37.70 \%
\end{aligned}
$$

Hasil Analisis Koefisien Determinasi menunjukan bahwa Layanan dan Kualitas Produk memiliki kontribusi sebesar 37.70 persen dalam menciptakan Loyalitas Pelanggan, dan sisanya sebesar 62.30 persen dipengaruhi oleh faktor lain-nya.

\section{Langkah-langkah McDonald's Hero Pajajaran Bogor dalam mempertahankan Loyalitas pelanggannya}

Langkah - langkah yang dilakukan oleh McDonald's Hero Pajajaran Bogor dalam mempertahankanloyalitas pelanggannya adalah :

1. melakukan pendekatan pada pelanggannya dengan membuat BLOG, dengan tujuan BLOG ini menanti segala informasi, report maupun masukan dari semua pelanggan. Dengan menyampaikan segala kegiatan yang Anda lakukan melalui email ke McDonald's Pusat.

2. Tetap konsisten dan sepenuh hati dalam melayani pelanggannya agar tercipta kepuasan pelanggan, menjadi pelanggan yang loyal.

3. Menjaga semua mutu standar, baik mutu standar pelayanan maupun mutu standar kualitas produknya.

\section{SIMPULAN}

Berdasarkan hasil analisa dan pembahasan, maka penulis menarik kesimpulan sebagai berikut :

1. Dari hasil penelitian mengenai pengaruh Layanan terhadap loyalitas pelanggan McDonald's Indonesia, diketahui bahwa fungsi $y=19,6225+0.375(x)$. Hasil ini mengandung arti bahwa jika pada saat ini layanan adalah sebesar 1, maka persamaan akan berubah menjadi $y=19,6225+0,375(1)$ yang berarti bahwa loyalitas pelanggan diketahui sebesar 0,375 atau dengan kata lain dapat ditarik kesimpulan bahwa loyalitas pelanggan pada saat ini adalah sebesar 19,9975. Persamaan regresi ini-pun berfungsi untuk meramalkan loyalitas pelanggan dimasa yang akan datang. Fungsi ini berfungsi untuk meramalkan apabila variabel (x) Layanan berubah maka variabel (y) Loyalitas Pelanggan-pun akan berubah. Hasil Analisis Koefisien Korelasi diketahui bahwa nilai $\mathrm{r}=0.465$, yang berarti bahwa terjadi hubungan yang signifikan dengan keeratan hubungan yang cukup atau sedang dan positif menunjukkan bahwa hubungan antara layanan dengan loyalitas pelanggan searah. Artinya jika layanan ditingkatkan maka loyalitas pelanggan akan meningkat. Hasil Analisis Koefisien Determinasi menunjukan bahwa Layanan memiliki kontribusi sebesar 21.62 persen dalam menciptakan Loyalitas Pelanggan, dan sisanya sebesar 78.38 persen dipengaruhi oleh kontribusi faktor Layanan lain-nya atau elemen Kualitas Pelayanan yang masih lemah.

2. Dari hasil penelitian mengenai pengaruh Kualitas Produk terhadap Loyalitas pelanggan McDonald's, diketahui bahwa fungsi $y=17,6887+0.425(x)$. Hasil ini mengandung arti bahwa jika pada saat ini Kualitas Produk adalah sebesar 1, 
maka persamaan akan berubah menjadi $\mathrm{y}=17,6887+0,425(1)$ yang berarti bahwa loyalitas pelanggan diketahui sebesar 0,425 atau dengan kata lain dapat ditarik kesimpulan bahwa loyalitas pelanggan pada saat ini adalah sebesar 18,1137. Persamaan regresi ini-pun berfungsi untuk meramalkan loyalitas pelanggan dimasa yang akan datang. Fungsi ini berfungsi untuk meramalkan apabila variabel $\left(\mathrm{x}_{2}\right)$ Kualitas Produk berubah maka variabel (y) loyalitas Pelanggan-pun akan berubah. Hasil Analisis Koefisien Korelasi diketahui bahwa nilai $\mathrm{r}=0,598$ yang berarti

bahwa terjadi hubungan yang signifikan dengan keeratan hubungan yang cukup atau sedang dan positif menunjukkan bahwa hubungan antara Kualitas Produk dengan loyalitas pelanggan searah. Artinya jika Kualitas Produk ditingkatkan maka loyalitas pelanggan akan meningkat. Hasil Analisis Koefisien Determinasi menunjukan bahwa Kualitas Produk memiliki kontribusi sebesar 35.76 persen dalam menciptakan Loyalitas Pelanggan, dan sisanya sebesar 64.24 persen dipengaruhi oleh kontribusi faktor Kualitas Produk lain-nya atau elemen Kualitas Produk yang masih lemah.

3. Dari hasil penelitian mengenai pengaruh Pelayanan dan Kualitas Produk terhadap loyalitas pelanggan McDonald's, diketahui bahwa fungsi $y=0.23309+0.4945(x)+0.5881(x)$. Hasil ini mengandung arti bahwa jika pada saat ini Layanan dan Kualitas Produk adalah sebesar 1, maka persamaan akan berubah menjadi $\mathrm{y}=0.23309+0,44945(1)+0.5881(1)$ yang berarti bahwa atau dengan kata lain dapat ditarik simpulan bahwa loyalitas pelanggan pada saat ini adalah sebesar 1.31569. Persamaan regresi ini-pun berfungsi untuk meramalkan loyalitas pelanggan dimasa yang akan datang. Fungsi ini berfungsi untuk meramalkan apabila variabel $(\mathrm{x})$ Layanan dan variabel $\left(\mathrm{x}_{2}\right)$ Kualitas Produk berubah maka variabel (y) Loyalitas Pelanggan-pun akan berubah. Hasil Analisis Koefisien Korelasi Ganda diketahui bahwa nilai $\mathrm{r}=0.614$, yang berarti bahwa terjadi hubungan yang signifikan dengan keeratan hubungan yang Kuat dan Korelasi positif menunjukkan bahwa hubungan antara Layanan dan Kualitas Produk dengan Loyalitas pelanggan searah. Artinya jika Layanan dan Kualitas Produk ditingkatkan secara bersama-sama maka loyalitas pelanggan akan meningkat. Hasil Analisis Koefisien Determinasi menunjukan bahwa Layanan dan Kualitas Produk memiliki kontribusi sebesar 37.70 persen dalam menciptakan Loyalitas Pelanggan, dan sisanya sebesar 62.30 persen dipengaruhi oleh kontribusi faktor Layanan dan Kualitas Produk lain-nya atau elemen Layanan dan Kualitas Produk yang masih lemah.

\section{DAFTAR PUSTAKA}

Ahmad Mardalis. 2005. Meraih Loyalitas Pelanggan, Benefit Jurnal Manajemenn dan Bisnis. Vol 9 No.2 2005 : hal 111-119.

Alma, Buchari. 2004 Manajemen Pemasaran dan Pemasaran Jasa CV ALFABETA Bandung.

Belk, Russel W. 1986, "ACR Presidential Address: Happy Thought," dalam Melaine Wallendorf dan Paul Anderson, eds, Advances in Consumer Research 14 (Provo, Utah: Assosiation for Consumer Research), 2.

Bowen JT \& Chen SL, 2001, "The Relationship between Customer loyalty and customer satisfaction", International journal of Contamporary Hospitality Manajemen, Vol. 13 No. 5.

Fathoni, Abdurahmat. 2006 Metodologi Penelitian \& Tekhnik Penyusunan Skripsi, Eka, Jakarta.

Gilbert, David. 2003. Retailing Marketing Management. 2th Edition. England, Endinburgh Gate: Pearson Educated Limited.

Kotler, Philip, dan Gary Amstrong. 2004. Dasar-Dasar Pemasaran. Alih Bahasa Alexander Sindoro, Penyunting Bahasa Bambang Sarwiji. Edisi Kesembilan. Jakarta : PT. Index. 
Service, Quality \& Loyalty
- dan Kevin L. Keller. 2008. Manajemen Pemasaran. Alih Bahasa Benyamin Mollan. Edisi Keduabelas. Jakarta : PT. Macanan Jaya Cemerlang.

Kotler, Philip. 2000. Manajemen Pemasaran Analisis, Perencanaan, Implementasi, dan Pengendalian. Edisi 1, alih bahasa Hendra Teguh, Salemba Empat, Jakarta.

Manjemen Pemasaran, alih bahasa Hendra Teguh, dkk, Edisi Millenium Jakarta, PT Prenhalindo,2002.

Kotler Philip dan Gery Armstrong. 2001. Dasar-dasar Pemasaran, alih bahasa Alexander Sindoro. Edisi 9, jilid 2, PT Prenhalindo, Jakarta.

Mubarak, M.M. and Puspitasari, R., 2012. MENGUKUR KEPUTUSAN NASABAH MELALUI ANALISIS BRAND ASSOCIATION (Studi Kasus pada Bank Muamalat Indonesia-Cabang Bogor). Jurnal Ilmiah Ranggagading (JIR), 10(1), pp.Halaman-45.

Natalia, P. and Mulyana, M., 2014. Pengaruh Periklanan Dan Promosi Penjualan Terhadap Keputusan Pembelian. Jurnal Ilmiah Manajemen Kesatuan, 2(14), pp.119128.

Nurendah, Y. and Mulyana, M., 2013. Analisis Pengaruh Kualitas Pelayanan Perpustakaan Terhadap Kepuasan dan Hubungannya dengan Loyalitas Mahasiswa. Jurnal Ilmiah Manajemen Kesatuan, 1(1), pp.91-105.

Pappers, D dan Rogers M., 1999, The One to One Manager Real World Lesson in Customer Relationship Management, New York: Double Day.

Parasuraman, Zeithaml, and Berry. 2006. Consumer Behavior, and Marketing Strategy. New York: The Free Press A Division of Macmillan Inc.

Puspitasari, R. and Mubarak, M.M., 2012. Perilaku Pembelian Produk Pakaian Bermerek Yang Dilakukan Staf Pengajar STIE Kesatuan Bogor. Jurnal Ilmiah Ranggagading (JIR), 12(1), pp.halaman-47.

Purwadarminta, W.J.S 2005 Kamus Besar Bahasa Indonesia. Edisi Ketig. Balai Pustaka, Jakarta.

Rangkuti, Freddy, Riset Pemasaran. PT Gramedia Pustaka Utama, Jakarta 1997.

Saladin, Djaslim 2004, Manajemen Pemasaran, Pelaksanaan dan pengendalian (Teori , Aplikasi dan Tanya Jawab), PT Linda Karya Bandung.

Saladin, Djaslim dan Yevis Marti Oesman, 1999, Intisari Pemasaran dan Unsur Pemasaran, PT. Media Iptek, Bandung.

Soemantri, Ating, dan Sambas Ali Muhidin. 2006. Aplikasi Statistik dalam Penelitian. CV Pustaka Setia, Bandung.

Sudrajat, Eka Wardana. 2007. Pengaruh Pelayanan Terhadap Kepuasan Pelanggan, Studi kasus PT Bina Nusa Rama. Skripsi, Universitas Guna Dharma.

Swasta Bashu dan Dharmmesth, 1999, Loyalitas Pelanggan. Sebuah Kajian Konseptual Sebagai Panduan Bagi Peneliti, Journal Ekonomi dan Bisnis Vol. 14 No.3 Hal . 7388.

Simonson, Itamar, 2005, "Determinants of Cusatomers' Responses to Customezed Offers : Conceptual Framework and Research Propositions," Journal of Maarketing, Vol. 69 (January), $32-45$.

Sulistiono, A. and Harni, B., 2012. Pengaruh Pelayanan Terhadap Kepuasan Konsumen. Studi Kasus Pada Biro Kerjasama Teknik Luar Negeri Sekretariat Negara. Jurnal Ilmiah Kesatuan (JIK), 9(2).

Tjiptono, Fandy. 2005, Pemasaran Jasa, Edisi Pertam, Bayumedia, Yogyakarta.

Umar Husein. 2002. Riset Pemasaran Jasa dan Perilaku Konsumen, PT Gramedia Pustaka Utama, Jakarta. 